ISSN: 2414-0325. Open educational e-environment of modern University, special edition (2019)

Eugenia Smyrnova-Trybulska

Associate Professor, Dr Hab, Head of the Department of Humanistic Education and Auxiliary Sciences of Pedagogy

University of Silesia in Katowice, Katowice, Poland

esmyrnova@us.edu.pl

ORCID: 0000-0003-1227-014X

\title{
EVOLUTION OF MEDIA COMPETENCES
}

\begin{abstract}
This article presents issues related to the evolution of media and media competences, a review and analysis of selected historical, technological and educational conditions in the context of the development of digital technologies. A comparison is also made between digital, information and media competences, current development trends and future trends. The differences and requirements between qualified media users and qualified users of information technology are becoming less and less distinct. The 3 generations of Media education - 1.0, 2.0 and 3.0 were described. The main purpose of media education in the first phase of development, referred to as media education 1.0, was to develop not only critical thinking skills towards the media and media messages, but also - in a general sense - critical attitude and autonomy. Media 2.0 education can be discussed in connection with the dynamic development of the Internet and information and communication technologies, including social media, at the beginning of the 21 st century. In the scientific discourse of recent years, the concept of ,algorithmic culture" has appeared, originally defining a set of cultural artefacts that are software products, related to video games, and now describing the phenomenon in which the Big Data logic of large-scale machine learning algorithms change how culture is practiced, processed and understood (Gillespie, 2014). This stage of evolution of Media education could be identified as Media education 3.0. AI and VR and AR can accelerate teaching and learning processes through immersion, collaboration among users, realistic simulations and multi-channel communication. The topic is quite important and current in the context of changes in the education system at various levels and the challenges involved in preparing new programs.
\end{abstract}

Keywords: media; media competences; evolution; development of digital technologies

Introduction. Currently, the task of forming media and IT competences of a modern specialist, in particular a teacher, is quite relevant. It is associated with the turbulent development of information and communication technologies, with the formation of a digital society in which most professions are associated with the searching, storage, processing, presentation and transmission of various data. Developing key competences, including digital, media as well as soft competences is one of the priorities of increasing, first of all, the contemporary properties of specialists and teachers.

Having considered researchers such as A.V. Fedorov, A.V. Sharikov, K.Tainer, N.V.Cicherina, N.Yu. Hlyzova, L.A. Ivanova, A.P. Zhdanko, EV. Basilieva, it can be stated that media competence is an integral part of the professional competence of future specialists in different areas of training in higher education educational institutions (Ananieva 2014: 22).

\section{EVOLUTION OF MEDIA EDUCATION}

\subsection{Media education 1.0.}

The main purpose of media education in the first phase of development, referred to as media education 1.0, was to develop not only critical thinking skills towards the media and media messages, but also - in a general sense - critical attitude and autonomy.

Renee Hobbs and Amy Jensen see this approach as a continuation of the rhetorical practice present in ancient Greece in the 5th century BC, which aimed to teach the art of politics through oratory and precise critical thinking (Hobbs, Jensen, 2009).

A significant impact on the development of a critical approach to the media - and thus on the development of a critical approach in the field of media education (the so-called critical media education) has been produced by such critics of modern society and culture as: Marshall McLuhan, Michel Foucault, Theodor Adorno, Herbert Marcuse, fohn Fiske, Neil Postman or 
Roland Barthes; they werecalled by Hobbs the ,intellectual ancestors” of media education (Hobbs, 2009), (Ptaszek, 2019: 160)

The Figure 1 below illustrates selected conditions for the evolution of media and computer development, media and information competences.

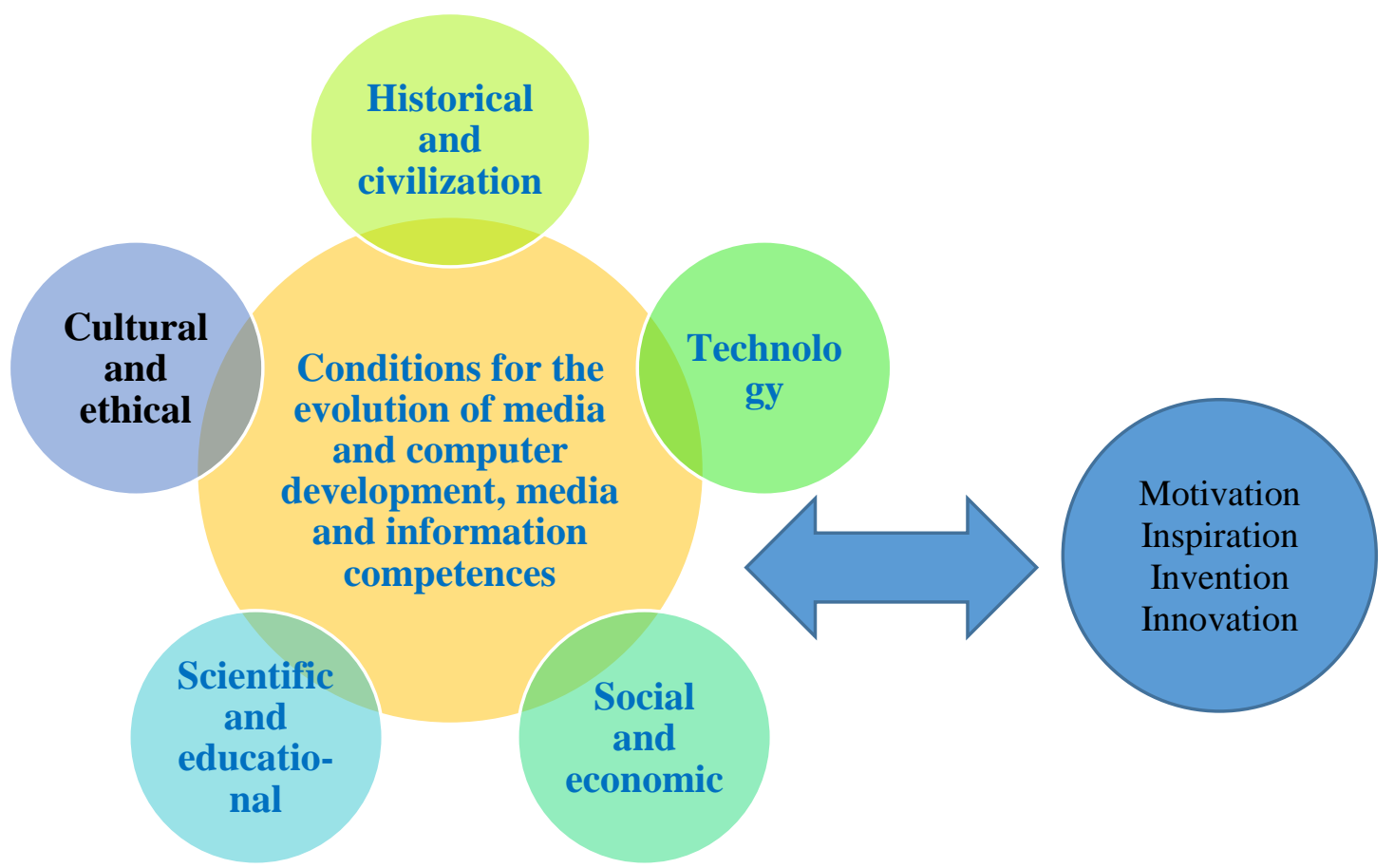

Fig. 1. The evolution of the media. From literacy to multimedia

Source: Own work

McLuhan was primarily concerned that literacy or book-based culture resulted in a decline in the use of the senses; text-based culture only required the use of the sense of sight.

This lack of use of other senses leads to „spiritual impoverishment” of the individual.

Fortunately, the electronic age gave hope because multimedia would require the use of additional senses to deal with it - multi-channel / multi-sensory.

The more sensual and various senses we use to engage in the media, the more complete our experience will be and the more spiritually fulfilled it will be.

So this is a form of media, not their specific content, which has the power to structure relationships and human action.

New forms of media introduce new forms of interpersonal interaction. Against this position, a second tradition derived from the observations of Raymond Williams (1974).

Some facts from the history of the media

The history of the media goes back to $3000 \mathrm{BC}$.

3000 B.C.E. - The first abacus in Babylonia is created, the first manual integer machine.

1445 - Johann Gutenberg, using movable fonts and a printing press, reflected an Old German poem on paper.

1452-1519 - Leonardo da Vinci designed a mechanical calculating machine with gears in the form of sketches, which was able to add 13-position decimal numbers. IBM built this machine from metals and it proved to be operational . Da Vinci's mechanical computational machine can be considered the beginning in the history of computing technology, a precursor of future electronic adding machines - the most important elements of modern ECM. 
At one time, a brilliant scholar was probably the only person who knew about the importance of the developed means that would facilitate computational work. There was no such need in those times.

German scientist Wilhelm Sickard (1592-1636) offers his variant of a computational machine for adding up and multiplying 6-digit numbers. The reason that inspired him to do so was to become acquainted with the work of the eminent astronomer I. Kepler, which required a great deal of calculations. In a letter dated 1623, Sickard provides drawings of the machine and a description of its operation. Unfortunately, the data about the fate of this machine is unknown.

1620 - Edmund Gunter from England invents the slide rule, which would become the progenitor of the electric calculator.

Blaise Pascal constructs - a mechanical machine - "pascaline", which is able to add numbers, created by him with the aim of facilitating the work of his father, while calculating taxes. In the course of 4 years he designed several more and more perfect machines. They were 6- and 8-position ones, operated on the basis of gears, and were able to add and subtract decimal numbers. Over 50 models of these machines were created. B. Pascal had a royal licence to produce them, but those pascalines were never put to practical use, although they were discussed and written about in those times. He also formulates the laws of divisibility of integers using the addition of digits. He develops a method for determining the binomial coefficients of any degree (Pascal's triangle).

1670 - Gottfried Wilhelm Leibniz, a German philosopher and mathematician, formulates the ideas of integral calculus and constructs a calculating machine that performs operations of adding and multiplying 12-digit decimal numbers. He added a special roller to the gears that allowed him to perform arithmetic operations. The modern integral parts of the computer are based on the Leibniz machine, which are arithmetic-logical devices.

1833 - Charles Babbage, an English mathematician called the IT pioneer, designs the first analytical machine operating on a principle similar to that of digital computers, called the ,arithmetic mill”. This machine was to perform basic mathematical operations, save input, intermediate data and results of final calculations. Data input and output were to be carried out on punched cards. The project was not implemented due to the low level of technology at the time. In 1991, in the Science Museum in London, a fragment (arithmometer) of the Second Differential Machine was made according to the original plans, proving the correctness of the design. The first program for the Babbage machine was written by Ada Lovelace.

There were other numerous examples of inventions in the field of computer technology and media development.

\section{Media education 2.0}

Media 2.0 education can be discussed in connection with the dynamic development of the Internet and information and communication technologies, including social media, at the beginning of the 21 st century.

New media practices related to active participation are emerging, primarily characterized by:

- unlimited self expression;

- allowing your own (amateur) creativity and sharing it with others;

- a kind of informal mentoring, thanks to which what is known to the more experienced is also available to new members of the community;

- community members' belief that their participation in culture is also beneficial to others, as well as a certain degree of social relationship with others (it is important what they think of the content created by other consumers) (Ptaszek, 2019) 
- participation in the creation of content and the ability to interact, reverse link, evaluate, comment on someone else's work.

- Users - active web space creators;

\section{Information literacy}

- In English-language literature, the term information literacy (IL) is used to describe the ability to effectively use information to accomplish assumed tasks and goals;

- According to Christine Bruce, although the idea of information literacy dates back to the 1970 s, it did not strengthen until the 21 st century as a key competence.

Although many organizations, researchers and scientists have attempted to describe information literacy, there is currently no commonly agreed one common definition for the term.

Definitions known from the literature most often define this concept as a set of skills related to obtaining information, from identifying information needs to their effective use (Borawska-Kalbarczyk, 2015: 131).

- This term was first used by the American educator Paul Zurkowski, then president of the US Information Industry Association, in 1974 in the report The Information Service Environment, Relationships and Priorities.

- As B. Torlińska (2004: 369) points out in her study, some „other definitions of the term Information Literacy approach the problem in a similar way, only slightly changing the scope of the skills involved.

- And so, for example, Doyle defines a person who efficiently uses information as someone who:

- recognizes the need for information, is aware that the right and complete information is the basis for intelligent decision making,

- identifies potential sources of information,

- applies effective search strategies,

- uses computers and other information sources,

- evaluates information, systematizes information for practical applications,

- integrates new information with existing knowledge and uses information to think critically and solve problem (see also Doyle, 1992).

The notion of information literacy in Polish literature on the subject can be translated, among others, as information skills, information skills, information fluency, information awareness, information literacy or information competences.

Among English synonyms and related terms such phrases are listed as:

- information skills, information literacy skills,

- information literacy competencies, information competence, information competence skills,

- information problem solving, information fluency, information handling,

- information empowerment, information technology (IT) skills,

- information and communication technology (ICT skills).

\section{Media and IT competences. UNESCO}

In 2011, UNESCO - the institution responsible for the official and worldwide dissemination of the term 'media education' since the 1970s - made an important change.

Due to technological progress in telecommunications and intensive dissemination of information created and made available daily by children and young people, the challenge of searching, choosing and assessing the relationship between media literacy (digital literacy) and digital literacy (digital literacy) is ambiguous.

There is no unanimity in this matter among researchers. There are two approaches that can be described as exclusive and inclusive. 
The first approach - exclusive - dominates among researchers representing mainly information sciences and supporters of information technology in education (including educators).

According to them, media competences (literary media) are understood very narrowly as the skills of critical understanding, creation and dissemination of media messages through various information channels (digital and non-digital) and are only one of the components of digital competences. (Ptaszek, 2019)

For example, for European Commission experts related to the DigCom project, media competences consist of IT (literacy), information (information literacy) and internet (literacy Internet) competences as digital competences.

The accuracy and reliability of such information has become a premise to synchronize the current requirements of modern society. The concept currently proposed by UNESCO is the ability to use media and information.

On the other hand, the other approach - inclusive - is common among media education supporters who consider media competences as superior to digital competences, which is mainly due to the broad understanding of the term 'media' referring to both mass media and new information channels, communication and social media.

According to David Buckingham, new digital media should not currently be perceived only in terms of information or technology, especially when one wants to look for more effective links between techno-logical experience at school and outside. (Ptaszek, 2019)

\section{Media Education (Digital Future)}

There are different terms in the literature on the subject for 'media education', and it is understood in different ways in other countries.

The terms of media, information, digital, audiovisual and IT education are functioning interchangeably.

It is conditioned by the rapid development of technology, the variety of forms and ways of transmitting information, as well as the change in the attitudes of the recipients themselves, who are also active participants in all these processes.

It seems, however, that these overlapping fields should be treated together, including them with the common term "media and information education” (combining with this issue different means of expression and communication, different sources of information and media), pointing to different approaches to the same reality communication (taking into account both technical competences in this area and the socio-cultural context of their application). This approach was proposed in the Digital Future document (Budyńska, Jezierska, 2015: p. 358)

\section{Media and information education in Poland}

Media and information education in Poland - an opening report prepared in 2013 by the Modern Poland Foundation: (...) in general, we treat media and information competences jointly and broadly.

Broad convergence - covering all media and information, audiovisual and film competences, critical and reading - seems to be the most appropriate direction for further activities (Digital Future. Media and information education in Poland - opening report, [online:] http://ngoteka.pl/bitstream/handle/item/94/Raport-CyfrowąPrzysz $\%$ c5\% $\% 20 \% c 5 \% 9 b \% c 4 \%$ 87-.pdf?sequence=1,).

IFLA also recommends broad coverage. (...) Media and information competences include: knowledge, attitude and all skills necessary to determine your own information needs. (Budyńska, Jezierska, 2015: p. 358) 


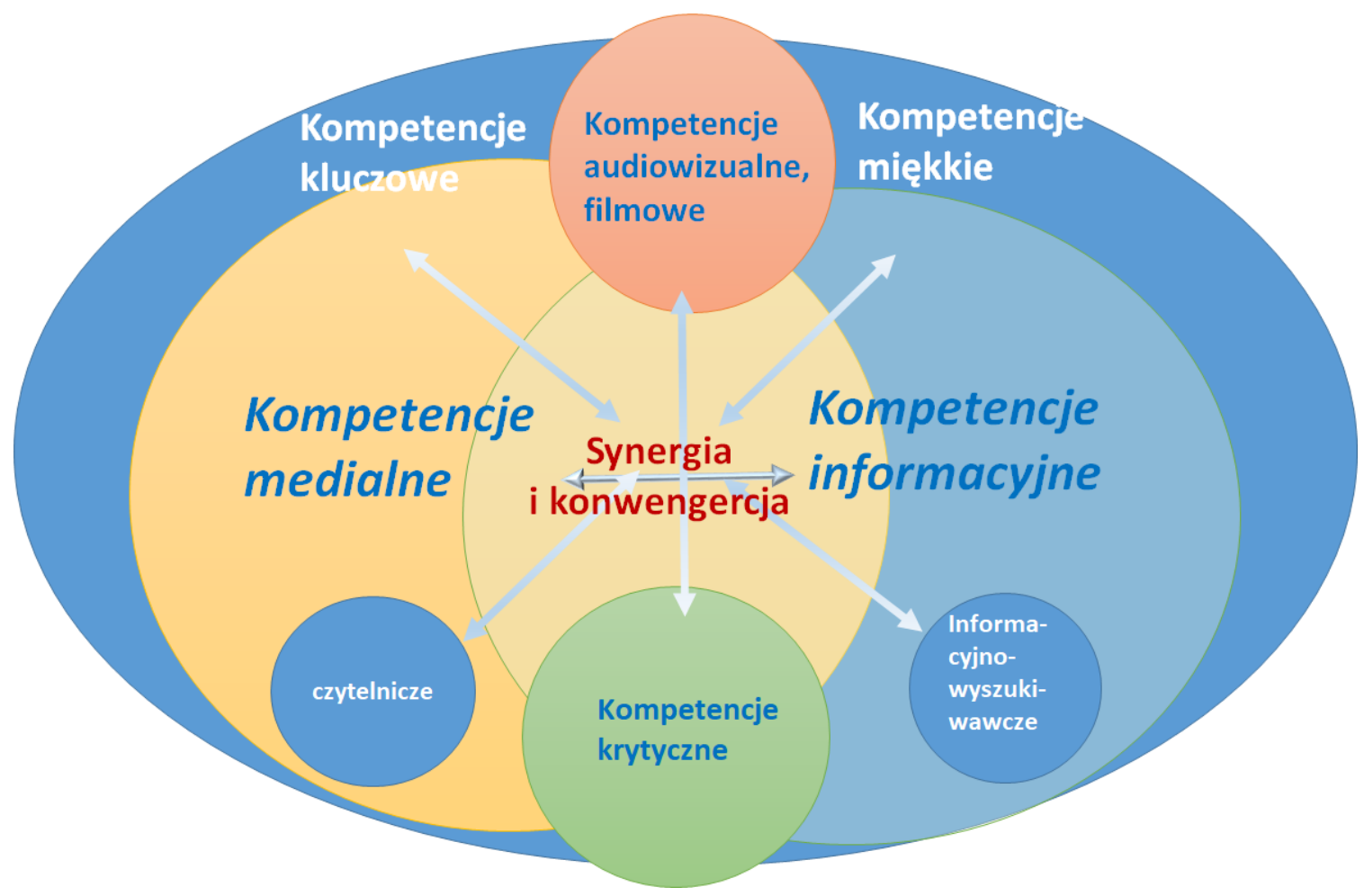

Fig. 2. Synergy and convergence of media and information competences Source: Own work

\section{LITERACY MEDIA. International experience. The Netherlands}

The role of the media is increasingly important in our society. It is difficult for us to do without them, and our communication has changed radically. This applies to all layers of the population in all stages of life.

The term „MEDIA LITERACY” means a set of competences that should be possessed and actively and consciously used in a media society.

Part of Mediawijzer.net, Sound and Vision is a national club for developing media literacy.

https://www.beeldengeluid.nl/en/knowledge/knowledge-themes/media-literacy

The impact of the media caused the launch of the National Expertise Center Mediawijzer.net in 2008. It was an initiative of the Dutch Ministry of Education, Culture and Science.

Mediawijzer.net aims to promote media literacy for children and young people between 0 and 18 years old. Mediawijzer.net has developed a Competency Model for media literacy that lists ten specific and useful competences that can be used by everyone in the field of media literacy:

\section{Knowledge / Understanding}

1. Understanding society's medialization

2. Understanding how media is created

3. Perception and understanding of color media reality

\section{Use / skills}

4. Used devices, software and applications

5. Orientation in the media environment

Communicating / Communicating

6. Information search and processing 
7. Creating content (content)

8. Participation in social networks strategy

9. Reflecting on one's own media usage

10. Achieving goals through the media

The model of LITERARY MEDIA (Netherlands), includes 10 competences described in https://www.mediawijzer.net/van-mediawijzer-net/competentiemodel/ $\quad$ and in https://www.youtube.com/watch?time_continue=260\&v=1MllJoZDLPY - video

For example level B1. Understanding of medialization of society

The media - old and new - are increasingly present in our lives. We are connected to computers, tablets, smartphones, televisions, radios, newspapers, game consoles and MP3 players for almost the whole day.

Our daily experiences are therefore increasingly determined by the media.

We read at peak times, we have more friends online, we spend the business day reading and sending emails, running fast with downloaded music in our ears and worrying about disasters and revolutions in countries we have never been to. This process, in which a wide range of media increasingly penetrates our world, is called the medialization of society.

Media literacy begins with awareness of the processes of mediation and their effects.

What exactly are these effects that are welcome and should be prevented, we do not yet know for sure. We know that the socialization of society is the subject of discussion by both the local hairdresser and the university as well as nujij.nl to De Wereld Draait Door.

Media literacy is: experiencing, thinking and discussing trends and consequences

The distinguishing feature of our time is medialization of society.

Each competence is described at 5 levels $\langle 0-4\rangle$

1) No awareness of the increasingly important role of the media in many areas of human existence.

2) Taking note of the growing use of new media, but failing to see the sense of its impact on the world of people.

3) Awareness that the media society requires new media skills.

4) Learning the more obvious effects of growing media on human existence, such as the fact that the media is always and everywhere present, that we are always connected, that more and more information comes to us, etc.

5) Ability to analyze the various effects of medialization in one's own way of life and shed light on it from many perspectives. To this end, the subject delves into the latest insights and ongoing discussions.

\section{Educational program. Workshops. Olympics}

Especially for education and partners in the field of media literacy, Sound and Vision develops educational programs, services and products between the media in which the promotion of media literacy among young people, young people and adults plays a major role.

This is always associated with testing for the above-mentioned media competence model. (https://www.beeldengeluid.nl/en/knowledge/knowledge-themes/media-literacy)

\section{Selected research results. Background.}

Greater use of the media can lead to a better understanding by children of how they can use these devices for what they might meet there.

Research shows that young children use the media more often than a few years ago, and therefore less often with parents.

Figure 6: Medium media literacy for children aged 0-6 according to parents. Looking at how media-qualified parents rated their children in recent years, it is clear that the media skills of young children can be described as' no 'rather than' skillfully (Figure 6). In all years, average results are below neutral (score 3 ) on a scale from 1 (not at all) to 5 (very good). 
At the same time, however, it seems that according to parents, children have been using media more easily and efficiently for years. (Nikken: 2019)

On average, about 6 different skills that have been presented in relation to all the 1 years:

- „They can start a movie or game themselves",

- „Can click on pop-up ads”

- „They know that movies or programs are not always real”,

- „They can find their way through games using symbols"-, parents have found that their children are more qualified in 2018 than in 2012.

- Children Anno 2018, about three-quarters point ahead. The increase in skills is particularly noticeable until 2015. According to parents, children were even in 2015 and 2016, when possession of tablets was the highest.

- Compared to 2012, the skill was then almost a whole higher point. These young nowchildren (motor) can cope well with modern technology; it was discovered in 2018 more than half of parents agreed that their child could touch, move or click touch screens.

Average media efficiency of children aged $0-6$ according to parents:

In 2012 - 1,99; 2013 - 2,25, 2014 - 2,56, 2015 - 2, 87; 2016 - 2,91; 2017 - 2,71; 2018 2,73. (Nikken, 2019: 15)

We can see that after 2016 the average media efficiency of children aged 0-6 decreases according to their parents. And this fact requires additional analysis and additional research.

Next interesting datas concern the number of minutes that children from 0 to 6 years spent using the media in 2012 and 2018. P. Nikken, (2019:10) presents on the Figure 4, which shows, that during 2012-2018 the number of minutes that children from 0 to 3 years spent in the media in 2012 and 2018 is greater than the number of minutes that children from 4 to 6 years spent in the media. And because it is especially important to update the media education of children in earlier age from 0 to 4 years, it is a huge challenge but necessary and expected.

The results of another research on a similar topic were described in a study by E. Brzyszcz (2018: 83-84): "Modern children are growing up in the world of media, which is why they are able to use devices such as tablets and smartphones. Considering this, it is worth noting that the age of initiation of using new technologies is decreasing. According to the research We Give Children Strength (2015), 64\% of children up to 6.5 years use mobile devices, and $25 \%$ of them do it every day; $26 \%$ of preschoolers have their own mobile device, and $62 \%$ play on a smartphone or tablet. Are therefore the technical skills of preschool and early school age children at the same level as their ability to selectively and rationally navigate the media space?"

THE DIGCOMPEDU FRAMEWORK responds to the growing awareness of many EU Member States that teachers need to be able to use the potential of digital technologies to improve and innovate education including in media and digital education.

The European Framework for the Digital Competence of Educators: DigCompEdu (2017) aims to capture and describe these teacher-specific digital competences by proposing 22 basic competences organized in 6 areas:

Area 1 is targeted at a broader professional environment, i.e. for teachers to use digital technologies in professional interactions with their colleagues, pupils, parents and other interested parties, for their individual professional development and the common good of the organization.

Area 2 analyzes the competences needed for the effective and responsible use, creation and sharing of digital resources for educational purposes.

Area 3 is dedicated to managing and managing the use of digital technologies in teaching and learning.

Area 4 concerns the use of digital strategies to improve evaluation. 
Area 5 focuses on the potential of digital technologies for student-centered teaching and learning strategies.

Areas 6 detail the specific pedagogical competences required to facilitate and increase the effectiveness of learners' digital competences.

Another important document is UNESCO ICT Competency Framework for Teachers (2017) which includes:

MODULE 1: UNDERSTANDING ICT IN EDUCATION

MODULE 2: CURRICULUM AND ASSESSMENT

MODULE 3: PEDAGOGY

MODULE 4: ICT

MODULE 5: ORGANIZATION AND ADMINISTRATION

MODULE 6: TEACHER PROFESSIONAL LEARNING

Media education programs. Models

Marcus Leaning (2009) distinguishes three different models and approaches in media education:

- approach to inoculation / protection;

- cultural / demystification approach and

- participatory approach that still exists in media education programs.

\section{Media competence}

Media competences, therefore, are broadly understood as specific knowledge and a set of skills that have been acquired in the process of targeted media education (Buckingham, 2003, p. 4).

In several major studies and reviews of media literature an informed decision was made to identify potential recipients of media education by age.

Therefore, media literacy has been tested in relation to: young children (e.g. Rideout et al., 2003); children (e.g. Marsh et al., 2005); young people (e.g. Buckingham, 2005); adolescents (e.g. Craig, 2003) and adults (e.g. Livingstone et al., 2005). (Leaning 2009: p.2)

Other authors (e.g. Penman and Turnbull, 2007) recognized media literacy without age restrictions.

While children are the main topic of research and commentary on media literacy rather than adults (Dennis, 2004), many ideas about children have also been applied to adults.

Many concerns are related to the negative impact of the media on children as well as other groups, for example those with low education (Buckingham, 1997; Petley, 1997). (Leaning 2009: p.2)

\section{What does ,media" mean? Continued}

The media, however, refer to many forms of communication, and one of the key debates that have taken place in media literacy circles is to prioritize some forms of media over others.

When we teach the media, which technologies or media technologies should we explore?

Buckingham proposes an approach to media education that he claims can be applied to „the entire spectrum of the media - from large budget cinema movies to snapshots that people do and deal with in everyday life" (2003, p. 4).

However, many other authors have argued that differences between the media, in particular the features of new media, may require a new approach to media education (Gauntlet, 2007; Merrin, 2008).

\section{Selected classifications}

The problem is even more complicated when we consider the difference between media forms and media texts.

Media forms include radio, television, internet technologies and computer game consoles, various types of mass print media, such as newspapers and magazines, and many others. 
Media texts usually refer to the content available on media forms, such as documentary film content, animations, websites, blogs, radio broadcasts, printed advertisements and computer games.

\section{Discussion. Suggestions}

As for teaching staff, it is worth using the potential of school libraries and librarian teachers who could act as media educators.

It is especially so, since the core curriculum emphasizes the role of school libraries, focusing, however, on their equipment, bypassing the possibility of using educated information specialists.

The potential of IT teachers, social and cultural teachers, as well as Polish and art teachers is not sufficiently exploited.

There is no question of their cooperation in achieving the goals of media education, although it is their subjects that are most filled with content related to the use and analysis of the media. Therefore, instead of „every teacher" - regarding responsibility for media and information education - a ,competent teacher” solution is proposed. (Dąbrowska, Drzewiecki, Jasiewicz, Lipszyc., Stunża, 2012: p. 201)

\section{Core curriculum for media and information education}

- A clear, comprehensible and uniform core curriculum for media and information education is a basic condition for the possibility of its actual conduct and assessment of student progress.

- The current dispersed model could be the basis for building at least several improved media and information education programs using today's school potential, but only if it is part of a coherent, future-oriented and comprehensive vision of media and information competence education. (Dąbrowska, Drzewiecki, Jasiewicz, Lipszyc., Stunża, 2012: p. 201).

\section{Important initiatives}

In 2007, a significant initiative was the global meeting on the subject of media education in Paris, which resulted in the issue of 12 Recommendations (Paris Agenda or 12 Recommendations for media education).

These recommendations confirmed the validity of the Grünwald Declaration, noting that its message is even stronger in the face of the emergence of the information society and knowledge societies in a global context.

The recommendations that develop and refine the guidelines of the Declaration relate to:

12 recommendations (Paris Agenda or 12 Recommendations for media education, 2007)

\section{The need to adopt an inclusive definition of media education.}

The inclusion of media education in school programs requires a precise definition of the scope of this concept. Currently, it is no longer just a distinction between education through the media understood as the didactic method and education for the media understood as the content of teaching, but about the location of media education in the economic and social environment undergoing constant changes that result from the development of information and communication technologies. This education applies to all types of media, regardless of their nature and the technology used.

The inclusive concept of media education has three basic goals:

a) giving all people access to all types of media as potential tools for understanding society and participating in democratic life;

b) developing the skills of critical analysis of both information and entertainment;

c) encouraging production, creativity and interactivity on various levels of media communication. (Federowicz, Ratajski, 2015, p. 19) 

rights.

2. Strengthening links between media education, cultural diversity and respect for human

3. Determining, based on the above principles, basic skills to master at individual educational levels, as well as systems for evaluating these skills.

4. Incorporating media education into teacher education.

5. Developing appropriate pedagogical methods providing for an increased level of student participation and a closer relationship between the school and the outside world.

6. Mobilizing people who contribute to the education system (program creators, school heads, school superintendents, etc.) to integrate media education with this system.

7. Mobilizing for media education representatives of the social sphere (including families, associations, media professionals) and regulatory bodies, as this education cannot be limited to the school environment.

8. Locating media education as part of lifelong learning and including adults as well.

9. Developing media education and interdisciplinary research in its field at the level of higher education.

10. Creating national, regional and international research networks in the field of media education.

11. Organizing international exchange in order to disseminate good practices regarding media education and exchange information on activities undertaken in this field.

12. Raising public awareness and mobilizing decision-makers for media education by UNESCO in cooperation with organizations such as the Council of Europe or the EU. (Federowicz, Ratajski, 2015, p. 19)

\section{Media education 3.0}

In the scientific discourse of recent years, the concept of ,,algorithmic culture" has appeared, originally defining a set of cultural artefacts that are software products, related to video games, and now describing the phenomenon in which the Big Data logic of large-scale machine learning algorithms change how culture is practiced, processed and understood (Gillespie, 2014) .

An algorithmic society creates a new economy of power, and its purpose is to know everything WHO DOES WHEN AND WHERE, and to predict who WHAT DOES WHEN AND WHERE.

In such an algorithmic society, the fundamental question is the issue of freedom of speech and taking regulatory actions against standards abusing their position as those entities that take actions against users based on Big Data, algorithms and artificial intelligence (Ptaszek, 2019).

Whoever is the ruler of artificial intelligence will rule the world.

Web 3.0 is based on large amounts of collected and processed data and uses mechanisms based on artificial intelligence, including machine learning and neural networks, at the same time to predict the behavior and needs of users and design them.

Intelligent algorithms learn specific behaviors during 'repeated training' and then propose specific solutions.

Interestingly, the idea of an intelligent network (called a semantic network) was formulated in 1998 by one of the creators of the World Wide Web - Tim Berners-Lee and concerned, among others, the exchange of information between machines, although BernersLee did not treat it as a network based on artificial intelligence. 
E-learning / Blended learning Games and Gamification
Artificial Inteligance

Robotics and STEM education

Virtual i Augmented Reality

\section{Internet of Things}

Adaptive learning

E-learning /

Blended learning

E-learning / Blended learning

Personalization of teaching / learning

Fig. 3. Technologies and Innovations in education: trends

Innovations: trends and possibilities

- Design - Exploration - Development

- Miniaturisation

- 3D production

- Environment

- Green energy,

- Sustainable environment

- Driverless Car

- Efficiency

- Increase in (internet) data transmission,

- Providing access to resources in this Open Source

- Intelligent traffic control

- Innovation partnership

- International cooperation

- Mutual benefits

- Human space flight missions

Interdisciplinary team:

- Creating a team with technical, educational and multicultural facilities.

- Inclusion of younger and older members

- Quantity and quantity: more ideas VS Quality ideas. Ideas should not be evaluated until the ideation session is completed.

- New projects should be built on previous ideas. Yes and introducing new ideas ..

- An error is not a completely negative and prohibited option

'Augmented reality' (AR) has become a new technology with enormous opportunities for use in education (Akçayır and Akçayır, 2017; Tecnologico de Monterrey, 2017).

It enables the combination of real-time digital and physical information using various technology formats, such as tablets or smartphones, to create this new reality, which has affected the number of applications created for AR (Fombona et al., 2018). (Cabero-Almenara, Fernández-Batanero, Barroso-Osuna, 2019) 
This mixed integration of physical and digital realities was performed at various levels, using QR codes, images, 3D objects, coordinate placement using GPS, to use thermal signatures (Schmalstieg and Hollere, 2016). Recently, Augmented Reality has gained more importance in the field of education.

This status has been achieved due to the ease of use as well as the availability of technical devices for students. The publication (Julio Cabero-Almenara, Jose María Fernandez-Batanero, Julio Barroso-Osuna, 2019) presents the results of research conducted with students enrolled in pedagogical studies at the Faculty of Education of the University of Seville. The goal was to understand the degree of technological acceptance of students during their interaction with the produced AR objects, the results achieved by students, and whether their gender influenced the acquisition of knowledge

To this end, three instruments were used to collect data: a multiple-choice test for analyzing student achievement after interaction, a diagnostic instrument Technology Acceptance Model (TAM), created by Davis (1989), and an ,ad hoc" instrument created so that students can assess class notes enhanced with created AR objects.

VW can accelerate teaching and learning processes through immersion, collaboration among users, realistic simulations and multi-channel communication.

Conclusions. It conclusion we can stress that in conditions of dynamic development of digital society, mass-media, global Internet environment, all citizen, regardless of age, should have media and information competences in order to function properly, develop themselves, be able to assess each information in a creative manner, successfully develop themselves professionally and be happy in private life. "We live in a moment of profound and long-term transformation of the media: old scenarios, which are used by the media industry or consumers consuming media content, are rewritten. Since these changes are still taking place dynamically, I would like to emphasize once again that media researchers should focus on both the media industry and media users. (Ptaszek, 2019: 302).

The huge role depends on the competence of teachers at different levels of education. For this module, "Development of media competences" should appear at all levels of all pedagogical programs of study.

\section{REFERENCES}

10 MEDIAWIJSHEID COMPETENTIES. Mediawizjer.net https://cdn.mediawijzer.net/wp-content/uploads/sites/6/2013/07/Competenties_Model_.pdf

Akçayır, M. \& Akçayır, G. (2017). Advantages and challenges associated with augmented reality for education: A systematic review of the literature. Educational Research Review, 20, 1-11. Online at https://www.researchgate.net/publication/334223033_ Augmented_Reality_in_Language_Education_A_Systematic_Literature_Review

Ananieva L. (2014). Forming foreign media competence of future philologists. Science and Education a New Dimension. Pedagogy and Psychology, II(18), Issue: 37, 21-24 www.seanewdim.com

Balkin J.M. (2018). Free Speechinthe Algorithmic Society; BigData, Private Governance, and New School Speech Regulation, „UCDavis LawReview” 2018, t. 51, s. 1151. July 22, 2018 https://!awreview.Iaw.ucdavis.edu/issues/51/3/Essays/51-3_Balkm.pdf

Borawska-Kalbarczyk K. (2015). Kompetencje informacyjne uczniów w perspektywie zmian szkolnego środowiska uczenia się. Warszawa: Wydawnictwo Akademickie „Żak”.

Brzyszcz, E. (2018). Potrzeba edukacji medialnej dzieci w wieku przedszkolnym i wczesnoszkolnym - ujęcie teoretyczne i praktyczne kształtowania kompetencji medialnych [The need for media education in preschool and early school age - a theoretical and practical 
approach shaping media competence] Pedagogika Przedszkolna i Wczesnoszkolna Vol. 61 (11)/2018 pp. 83-91 [Pre-school and early school education Vol. 61 (11) / 2018]

Buckingham, D. (1997) News media, political socialization and popular citizenship: Towards a new agenda. Critical Studies in Media Communication. 14 (4), 344-366

Buckingham, D. (2003) Media Education: Literacy, Learning, and Contemporary Culture. Publisher: Polity Press Cambridge

Budyńska B. \& Jezierska M. (2015). Edukacyjne formy pracy bibliotek publicznych w Polsce oraz wykorzystywanie nowych technologii informacji i komunikowania s. 357-398 W: Michał Federowicz, Sławomir Ratajski (red.). O potrzebie edukacji medialnej w Polsce. Krajowa Rada telefonii i telewizji.

Cabero-Almenara, J., Fernández-Batanero, J. M., \& Barroso-Osuna, J. (2019). Adoption of augmented reality technology by university students. Heliyon, 5(5), e01597. doi:10.1016/j.heliyon.2019.e01597

Craig, D. (2003). Instant Messaging: The Language of Youth Literacy. Stanford: Stanford University

Cyfrowa Przyszłość. Edukacja medialna i informacyjna w Polsce - raport otwarcia, http://ngoteka.pl/bitstream/handle/item/94/Raport-Cyfrowa-

Przysz\%c5\%82o\%c5\%9b\%c4\%87-.pdf?sequence $=1$

Dąbrowska A.J., Drzewiecki P., Jasiewicz J., Lipszyc J., Stunża G.D. (2012) 12.Kształtowanie kompetencji medialnych i informacyjnych $\mathrm{w}$ podstawach programowych MEN [Shaping media and information competences in the curricula of the Ministry of Education, p. 201] s. 193-201

https://nowoczesnapolska.org.pl/wp-content/uploads/2012/01/

Przysz\%C5\%82o\%C5\%9B\%C4\%87-rozdzia\%C5\%82-12.pdf

Cyfrowa-

Dennis E.E. (2004) Out of Sign and Out of Mind: The Media Literacy needs for GrownUps. American Behavioral Scientist 48(2) 202-211

DigCompEdu (2017).

https://ec.europa.eu/jrc/en/publication/eur-scientific-and-technical-research-reports/europeanframework-digital-competence-educators-digcompedu

Doyle, C. (1992). Outcome Measures for Information Literacy within the National Education Goals of 1990: Final Report of the National Forum on Information Literacy. Summary of Findings. Washington DC: US Department of Education.

Federowicz, M. \& Ratajski, S. (2015). O potrzebie edukacji medialnej w Polsce. Polski Komitet do spraw UNESCO, Krajowa Rada Radiofonii i Telewizji. Studio 2000 ISBN 978-83943906-1-7

Fombona Cadavieco J., Vazquez-Cano E., Del Valle Mejias M.E. (2018) Analysis of geolocation and augmented reality on mobile devices, social and educational proposals related to the environment and field trips PROFESORADO-REVISTA DE CURRICULUM Y FORMACION DE PROFESORADO 22(4), 197-222

Gillespie T. (2014). The Relevance of Algorithms, [In:] Media Technologies, T. Gillespie, P. Boczkowski, K. Foot (eds.), MIT Press, Cambridge 2014

Hobbs, R. \& Jensen, A. (2009) The Past, Present, and Future of Media Literacy Education, „Journal of Media Literacy” Vol. 1, 2009, 1-11. January 16, 2018 https://files.eric.ed.gov/ fulltext/EJ1095145.pdf (accessed 16.01.2018)

https://www.beeldengeluid.nl/en/knowledge/knowledge-themes/media-literacy

https://www.mediawijzer.net/van-mediawijzer-net/competentiemodel/

https://www.youtube.com/watch?time_continue=260\&v=1MllJoZDLPY

Iene Miene Media Review 2012 - 2018 
https://www.mediawijzer.net/wp-content/uploads/sites/6/2019/03/Iene-Miene-Media-reviewMUD19.pdf

Kotsilieris, T. \& Dimopoulou, N. (2013) „The Evolution of e-Learning in the Context of 3D Virtual Worlds" Article in Electronic Journal of e-Learning · June 2013 https://www.researchgate.net/publication/237201495

Leaning, M. (2009). Chapter 1 Theories and models of media Literacy In M. Leaning (Ed.) (2009). Issues in Information and Media Literacy: Volume 1: Criticism, History and Policy. Santa Rosa: Informing Science Institute, 1-17

Leaning, M. (Ed.) (2009). Issues in Information and Media Literacy: Volume 1: Criticism, History and Policy. Santa Rosa: Informing Science Institute.

Livingstone, S. van Couvering, E \& Thumim N (2005). Adult Media Literacy: A Review of the Research Literature, London: OFCOME

Marsh J., Brooks, G., Hughes, J., Ritchie, L, Roberts S., Wright K. (2005). Digital beginnings: Young children's use of popular culture, media and new technologies. Sheffield: Literacy Research Centre University of Sheffield

Mediawijzer2005.net

Nikken, P. (2019). Iene Miene Media: Een review van het mediagebruik van kinderen tussen de 0 en 6 jaar in Nederland sinds 2012. Iene Miene Media Review 2012 - 2018 https://www.mediawijzer.net/wp-content/uploads/sites/6/2019/03/Iene-Miene-Media-reviewMUD19.pdf

Ogonowska A. (2015) Kompetencje medialne W: Michał Federowicz, Sławomir Ratajski (red.). O potrzebie edukacji medialnej w Polsce. Krajowa Rada telefonii i telewizji, 97-145 http://www.unesco.pl/sourcesmedia/index-125.html

Paris Agenda or 12 Recommendations for media education (2007)

Penman, R. and S. Turnbull (2007), Media literacy --- concepts, research and regulatory issues. Canberra, Australian Communications and Media Authority.

Petley, J. (1997). Us and team. In N. Barker, J. Petley, (eds.) Ill Effects: The MediaViolence Debate. London: Routlage

Ptaszek G. (2019) Edukacja medialna 3.0. Krytyczne rozumienie mediów cyfrowych w dobie Big Data i algorytmizacji. Kraków: Wydawnictwo Uniwersytetu Jagiellońskiego

Rekomendacje IFLA (INTERNATIONAL FEDERATION OF LIBRARY ASSOCIATIONS AND INSTITUTIONS) $\mathrm{W}$ sprawie kompetencji medialnych i informacyjnych,

http://www.sbp.pl/repository/SBP/sekcje_komisje/komisja_ds_edukacji_informacyjnej/Reko mendacje_IFLA.pdf

Rideout, V., J., Wartella, E.A., Vandewater, E.A. (2003). Zero to Six ELECTRONIC MEDIA IN THE LIVES OF INFANTS, TODDLERS AND PRESCHOOLERS Fall Henry J. Kaiser Family Foundation and the Children's Digital Media Centers (CDMC).

Równy, A. (2015). Współczesne media i wychowanie. Wyzwania dla edukacji medialnej. Inspiracje 2015.

https://www.youtube.com/watch?v=6bTYKN23nfA\&t=104s

Schmalstieg, D. \& Hollere, T. (2016). Augmented Reality. Principles and practice. Boston: Addison-Wesley.

Smyrnova-Trybulska E. (2018) Technologie informacyjno-komunikacyjne i e-learning we współczesnej edukacji. Katowice: Wydawnictwo Uniwersytetu Śląskiego w Katowicach.

Tecnologico de Monterrey. (2017). ReporteEduTrends. Radar de Innovacion Educativa 2017 [EduTrends Report. Educational Innovation Radar 2017]. Monterrey: Tecnologico de Monterrey. 
Torlińska B., (2004). Alfabetyzm społeczeństwa wiedzy a kompetencje informacyjne. W: Strykowski W., Skrzydlewski W., red., 2004: Kompetencje medialne społeczeństwa wiedzy. Poznań: Wydawnictwo eMPi2, 368-379.

UNESCO ICT Competency Framework for Teachers (2017)

Williams, R., (1974). Television: Technology and Cultural Form. London and New York: Routledge.

\title{
ЕВОЛЮЦІЯ МЕДІА КОМПЕТЕНТНОСТЕЙ
}

\author{
Евгенія Смирнова-Трибульська \\ Доцент, доктор наук, завідувачка кафедрою гуманістичної освіти та допоміжних педагогічних дисциплін \\ Сілезький Університет у Катовіце, Катовіце, Польща \\ esmyrnova@us.edu.pl \\ ORCID: 0000-0003-1227-014X
}

\begin{abstract}
Анотація. Ця стаття висвітлює питання, пов'язані 3 еволюцією медіа та медіа компетентностей, знайомить 3 оглядом та аналізом обраних історичних, технологічних та освітніх умов у контексті розвитку цифрових технологій. Також зроблено порівняння цифрової, інформаційної та медіа компетентностей, сучасних та майбутніх трендів розвитку. Різниця між кваліфікованими користувачами медіа та кваліфікованими користувачами інформаційних технологій та вимогами до них стає все менш і менш виразною. Описано три покоління медіа освіти - 1.0, 2.0. та 3.0. Основною метою медіаосвіти першої фази розвитку, визначеної як медіаосвіта 1.0, було не тільки розвинути навички критичного мислення щодо медіа та медіа повідомлень, але й загалом критичне ставлення та автономність. Медіаосвіта 2.0 може обговорюватись у зв'язку з динамічним розвитком інтернету та інформаційнокомунікаційних технологій, включаючи соціальні медіа, на початку 21го століття. У науковому дискурсі останніх років з'явилася концепція “алгоритмічної культури”, яка вперше визначила набір культурних цінностей - програмних продуктів, пов'язаних 3 відеоіграми, які наразі описуют феномен, як біг дата логіка масштабних алгоритмів машинного навчання змінює те, як культура реалізується та розуміється (Гіллеспі, 2014). Цей етап еволюції медіаосвіти може бути визначений як медіаосвіта 3.0. Штучний інтнлнкт, віртуальна реальність на доповнена реальність можуть прискорити процеси навчання та викладання через занурення, співпрацю між користувачами, реалістичне моделювання та мультиканальну комунікацію. Тема є дуже важливою та актуальною в контексті змін в системі освіти на різних рівнях і враховуючи виклики, які виникають при підготовці нових програм.
\end{abstract}

Ключові слова: медіа; медіа компетенції; еволюція; розвиток цифрових технологій

KA2 CBHE - 586098-EPP-1-2017-1-UA-EPPKA2-CBHE-JP This project has been funded with support from the European Commission. The content of the article reflects the views only of the author, and the Commission cannot be held responsible for any use which may be made of the information contained therein. 